\title{
Current Approaches to Surgical Antimicrobial Prophylaxis and Use of Antimicrobial Prophylaxis in Urological Procedures
}

\author{
Cerrahi Öncesi Profilakside Güncel Yaklaşımlar Işığında Ürolojik Preoperatif Antibiyotik \\ Uygulamaları
}

\author{
Pınar Şen, Tuna Demirdal \\ İmir Katip Çelebi University, Atatürk Training and Research Hospital, Department of Infectious Disease and Clinical Microbiology, İmir, Turkiye
}

\begin{abstract}
Surgical site infections (SSIs) are the most common and preventable type of healthcare-associated infections in low and middle-income countries and affect one-third of patients that have undergone surgical procedures. As the number of surgical procedures performed increases, the prevention of SSIs becomes more important. It is considered that, it is possible to prevent approximately half of all SSI cases. However, due to the contribution of many factors to the development of SSIs, it may be difficult to effectively prevent these infections, and there is a need to take various preventive measures before, during and after surgery. This review presents the current recommendations on the use of prophylactic antimicrobial agents for the prevention of SSIs and recommendations about antimicrobial prophylaxis in urological procedures.
\end{abstract}

Keywords: Surgical site infections, antibiotics, prophylaxis

$\ddot{0 z}$

Cerrahi alan enfeksiyonları (CAE) en sık görülen sağlık bakımıyla ilişkili enfeksiyonlar olup önlenebilir olması nedeniyle önem arz etmektedir. CAE önlenmesi için uygulama çeşitleri gittikçe artmakta ve buna bağlı olarak kanıta dayalı müdahale talepleri gün geçtikçe artmaktadır. Bu nedenle önceden yayınlanan kılavuzlara ek güncelleme ihtiyacı doğmaktadır. Yeni ve güncellenmiş öneriler sadece sağlık mensupları için değil, aynı zamanda profesyonel dernek ve kuruluşlar için de bir kaynak olabilme özelliğini taşımaktadır. Bu derlemede CAE önlemeye yönelik profilaktik antimikrobiyal ajan kullanımıyla ilgili güncel önerileri sunmak amaçlanmıştır.

Anahtar Kelimeler: Cerrahi alan enfeksiyonları, antibiyotik, profilaksi

\section{Introduction}

Healthcare-associated infections are the most important adverse events that affect patient safety across the globe (1). The World Health Organization (WHO) has reported that surgical site infections (SSIs) are the most common and preventable type of healthcare-associated infections in low- and middle-income countries and affect one-third of patients that have undergone surgical procedures $(1,2)$. According to the Ministry of Health in Turkey, SSIs are the third most common healthcare infections in the country, accounting for approximately $20 \%$ of all infections
(2). In Turkey, the incidence of SSIs after surgery has been reported to be $1 \%$ by the National Hospital Infection Control Unit whereas it is $1.9 \%$ in the United States $(1,3,4,5)$.

As the number of surgical procedures performed increases, the prevention of SSIs becomes more important (6). It is considered that by using evidence-based strategies, it is possible to prevent approximately half of all SSI cases (7). However, due to the contribution of many factors to the development of SSIs (8), it may be difficult to effectively prevent these infections, and there is a need to take various preventive measures before,

Correspondence: Pınar Şen MD, İzmir Katip Çelebi University, Atatürk Training and Research Hospital, Department of Infectious Disease and Clinical Microbiology, İzmir, Turkiye Phone: +90 $5058946042 \quad$ E-mail: pinarozdemirsen@gmail.com ORCID ID: orcid.org/0000-0003-1365-3329 Received: 11.08 .2017 Accepted: 23.08 .2017

Cite this article as: Şen P, Demirdal T. Current Approaches to Surgical Antimicrobial Prophylaxis and Use of Antimicrobial Prophylaxis in Urological Procedures. J Urol Surg 2017;4:159-166. 
during and after surgery. Improving surgical techniques and ventilation in the operating room, sterilization, barrier precautions, and antibiotic prophylaxis are among the main measures for preventing SSI-related morbidity and mortality $(8,9)$. Thus, surgeons, infectious disease specialists and healthcare workers play a major role in protecting patients from SSIs (2). This review presents the current recommendations on the use of prophylactic antimicrobial agents for the prevention of SSIs, provided by various guidelines [WHO, Centers for Disease Control and Prevention (CDC), American Society of HealthSystem Pharmacists, the Infectious Diseases Society of America, the Surgical Infection Society, the Society for Healthcare Epidemiology of America and the European Association of Urology (EAU)].

\section{Definition of Surgical Site Infections}

Different definitions have been made in relation to SSIs, however, all sources agree that there is no single objective gold standard test for these infections (10). According to the definition provided by CDC, SSI is a post-operative infection that occurs at the site of incision, in the organ or at the surgical site (10). Based on this definition, SSIs are divided into the following three classes; superficial incisional, deep incisional, and organ/ space (11). Superficial and deep incisional SSIs are further classified as primary or secondary according to the infection being identified in the first incisional line or second incisional line in the presence of multiple incisions, respectively $(8,11)$. Taking the day of surgery as the first day, superficial incisional
SSIs are defined as the presence of infections in the skin and subcutaneous tissue that develop within the first 30 days of procedures performed with an incision $(8,11)$. Deep incisional SSIs are infections that develop in the deep tissue incision, such as the muscle or fascia within 30 or 90 days of surgery, and lastly, organ/space SSIs are those that involve any body region deeper than the muscle/fascia layer and develop within 30 or 90 days of surgical intervention (11). Table 1 shows the types of surgery in which 30-day and 90-day surveillance for SSIs are undertaken.

The degree of wound contamination is one of the most important factors in the development of SSIs (12). Surgical wounds are divided into the four classes of clean, cleancontaminated, contaminated, and dirty-infected (2). According to the US National Nosocomial Infections Surveillance (NNIS) system, the rate of infection is $1-3 \%$ in clean wounds, $3-10 \%$ in clean-contaminated wounds, 5-15\% in contaminated wounds, and $7 \%$ in dirty-infected wounds (12).

\section{Causative Microorganisms}

The main source of SSI-causative microorganisms is endogenous fluoride from the mucous membranes, skin and intestinal system (9). The most determinative factor in determining the agents to be used in antibiotic prophylaxis is the identification of microorganisms and resistance patterns that are most often the agents of SSIs. The presence of more comorbid diseases in surgical patients in recent years and the emergence of pathogens resistant to antimicrobial agents lead to additional cost and

Table 1. Surveillance periods according to surgical procedure (11)

\begin{tabular}{|c|c|}
\hline 30-day surveillance & 90-day surveillance \\
\hline $\begin{array}{l}\text { - Abdominal aortic aneurysm repair } \\
\text { - Shunt for dialysis } \\
\text { - Neck surgery } \\
\text { - Kidney surgery } \\
\text { - Exploratory laparotomy } \\
\text { - Limb amputation } \\
\text { - Vaginal/abdominal hysterectomy } \\
\text { - Cesarean section } \\
\text { - Appendix/small colon/colon/rectal surgery } \\
\text { - Carotid endarterectomy } \\
\text { - Laminectomy } \\
\text { - Gastric surgery } \\
\text { - Ovarian surgery } \\
\text { - Prostate surgery } \\
\text { - Bile duct, liver or pancreatic surgery } \\
\text { - Spleen surgery } \\
\text { - Thyroid and/or parathyroid surgery } \\
\text { - Thoracic surgery } \\
\text { - Liver/kidney/heart transplant }\end{array}$ & $\begin{array}{l}\text { - Open reduction of fracture } \\
\text { - Herniorrhaphy } \\
\text { - Breast surgery } \\
\text { - Cardiac surgery } \\
\text { - Coronary artery bypass graft (with both chest and donor site incisions } \\
\text { or chest incision only) } \\
\text { - Hip/knee prosthesis } \\
\text { - Craniotomy } \\
\text { - Peripheral vascular bypass surgery } \\
\text { - Pacemaker surgery } \\
\text { - Spinal fusion } \\
\text { - Ventricular shunt }\end{array}$ \\
\hline
\end{tabular}


difficulties in the treatment of SSIs $(13,14)$. Therefore, it is important to determine the most frequent bacterial agents. The most common pathogens reported in one or more SSIs by 1029 health institutions include; Staphylococcus aureus (30.4\%), coagulase-negative staphylococci (11.7\%), Escherichia coli (9.4\%), Enterococcus faecalis (5.9\%), Pseudomonas aeruginosa (5.5\%), Enterobacter spp. (4\%), and Klebsiella spp. (4\%) (15). Endogenous and exogenous fungi, such as Candida albicans rarely present as the cause of SSIs (15).

\section{Surgical Site Infection Risk Factors}

There are many factors that affect surgical wound healing and the possibility of infection (16), including patient-related (endogenous) and procedure-related (exogenous) variables (1). Some factors, such as patient age and gender are fixed but other potential variables, e.g., nutritional status, smoking, rational antibiotic use, compliance with asepsis-antisepsis techniques, technical conditions of the operating room, and intraoperative techniques, can be improved to provide positive surgical outcomes $(1,16)$. A systematic review of 57 studies conducted in various countries showed that a high body mass index, severe wound class, diabetes, and a high NNIS risk index were associated with increased SSIs (17). The NNIS index is a classification developed by the CDC to identify risk of SSIs after surgery and compare the infection rates between surgical patients (18). This scoring system is based on different variables, such as the physical status score in the scale developed by the American Society of Anesthesiologists and the duration of operation (18). Other risk factors include increased prevalence of resistant microorganisms, increased number of patients with comorbidities and immunosuppression due to the prolonged life span, and the increasing number of surgical interventions undertaken for these patients (e.g., prosthetic applications and organ transplantation) (8), as well as non-compliance with surgical asepsis and inappropriate use of antibiotics $(8,19)$.

\section{Recommendation Categories}

Recommendations regarding the prevention of SSls have been grouped into the following categories based on a standard system reflecting the level of supporting evidence and regulations (20):

- Category IA: A strong recommendation supported by high to moderate quality evidence suggesting net clinical benefits or harms.

- Category IB: A strong recommendation supported by low quality evidence suggesting net clinical benefits or harms or an accepted practice (e.g., aseptic technique) supported by low to very low-quality evidence.

- Category IC: A strong recommendation required by state or federal regulation.
- Category II: A weak recommendation supported by any quality evidence suggesting a trade-off between clinical benefits and harms.

- No recommendation/unresolved issue: An issue for which there is low to very low-quality evidence with uncertain tradeoffs between the benefits and harms or no published evidence on outcomes deemed critical to weighing the risks and benefits of a given intervention.

\section{Current Recommendations}

\section{- Parenteral Antimicrobial Prophylaxis}

Preoperative antimicrobial agents should only be administered in the presence of indications based on published clinical practice guidelines and in cases where sufficient bactericidal concentrations of serum and tissue are achieved with incision (category IB) (Table 2) $(20,21,22)$. The 1999 CDC guidelines and other clinical practice guidelines for the prevention of SSIs recommend a single intravenous dose of prophylactic antibiotic only when it is indicated as appropriate (16). For most prophylactic agents, the 1999 CDC guidelines recommend the administration of antimicrobial prophylaxis 60 minutes before incision, but for vancomycin and fluoroquinolones, this should be administered 60 to 120 minutes before incision $(1,16,21)$. However, there is no clear data concerning the need for complete or partial infusion of the parenteral antibiotic dose prior to surgical incision (20).

Preoperative antimicrobial agents should not be administered based on clinical outcomes (in cases of no recommendation/ unresolved issue) (20).

In all cesarean procedures, an appropriate parenteral prophylactic antimicrobial agent should be administered before skin incision (category IA) (20). Clinical practice guidelines suggest using prophylactic antibiotics 60 minutes prior to skin incision in both elective and emergency cesarean sections $(21,22,23)$. Antimicrobial prophylaxis is no longer recommended after cord clamping (16).

In clean and clean-contaminated procedures, no additional prophylactic antimicrobial agents should be administered after the closure of surgical incision even in the presence of a drain (category IA) (20).

A review of the literature shows the lack of randomized controlled trials evaluating the benefits and ill effects of weightadjusted parenteral antimicrobial prophylaxis and their impact on SSI risk (no recommendation/unresolved issue) (20). However, recommendations have been made based on observational and pharmacokinetic data (20). Clinical practice guidelines suggest increasing the dose of single-dose prophylactic antimicrobial 
agent to be used in obese and morbidly obese patients $(21,22,23,24)$. For example, for cefazolin, $>2 \mathrm{~g}$ is recommended for patients weighing $60-80 \mathrm{~kg}$ and $3 \mathrm{~g}$ for patients $>120 \mathrm{~kg}$ $(21,23,25)$. The appropriate dose for aminoglycosides should be calculated by adding $40 \%$ of the difference between the actual and ideal body weights of patients to their ideal body weight $(21,24,26)$. For vancomycin, the recommended dose is $15 \mathrm{mg} /$ $\mathrm{kg}$ (25).

There are only a limited number of randomized controlled trials that have investigated the benefits and ill effects of a repeated intraoperative dose of parenteral prophylactic antibiotics to prevent SSI (no recommendation/unresolved issue) (20). However, suggestions have been made based on observational and pharmacokinetic data (20). Clinical practice guidelines indicate that prophylactic antimicrobial agents should be repeated in cases of prolonged treatment (when the duration of the surgical procedure exceeds the prophylactic half-life of the antibiotic or is longer than 3-4 hours), blood loss of more than $1500 \mathrm{~mL}$, and widespread burns $(21,24,25,27)$.

A wide-scale meta-analysis of the efficacy and optimal application duration of postoperative antimicrobial prophylaxis demonstrated high quality evidence that there was no benefit in continuing antimicrobial prophylaxis after the closure of surgical incisions $(28,29,30)$. A meta-analysis of three randomized controlled trials in cardiovascular surgery showed moderate quality evidence that the continuation of antimicrobial prophylaxis did not provide any additional benefits after intraoperative closure of surgical incision $(28,31,32)$.

Table 2. Suggested empiric antibiotics by surgical procedure $(21,22)$

\begin{tabular}{|c|c|c|}
\hline Surgery & Suggested antibiotics & B-lactam allergy \\
\hline Cardiac/vascular/thoracic surgery & Cefazolin & Vancomycin 1 \\
\hline Cardiac surgery with prosthetic material & Cefazolin + vancomycin & Vancomycin 1 \\
\hline Cardiac device insertion (pacemaker implantation) & Cefazolin & Vancomycin 1 \\
\hline Gastroduodenal surgery & Cefazolin & Vancomycin 1 + gentamicin \\
\hline Biliary tract surgery & Cefazolin & Metronidazole + levofloxacin \\
\hline Colorectal surgery, appendectomy & Cefazolin + metronidazole & Metronidazole + levofloxacin \\
\hline Other general surgery (hernia repair, breast) & Cefazolin & Vancomycin 1 \\
\hline Gynecological (hysterectomy), cesarean delivery & Cefazolin & Clindamycin 1 + gentamicin \\
\hline \multirow[t]{5}{*}{ Head and neck surgery } & Clean: Cefazolin & Clindamycin \\
\hline & Clean-contamined: & \\
\hline & • Ear/sinonasal procedure: Cefazolin & \\
\hline & $\begin{array}{l}\text { - Oral mucosal procedure: Cefazolin + } \\
\text { metronidazole }\end{array}$ & \\
\hline & Contamined: Cefazolin + metronidazole & \\
\hline Neurosurgery & Cefazolin & Vancomycin 1 \\
\hline Orthopedic surgery & Cefazolin & Vancomycin 1 \\
\hline Plastic surgery & Cefazolin & Vancomycin 1 \\
\hline \multirow[t]{4}{*}{ Urological surgery² } & Cefazolin & Clindamycin2a + gentamicin2b \\
\hline & & $\begin{array}{l}\text { Open/laparoscopic surgery: (clean) (skin } \\
\text { incision, does not involve genitourinary } \\
\text { tract) Clindamycin } 2 a\end{array}$ \\
\hline & $\begin{array}{l}\text { Open/laparoscopic surgery involving } \\
\text { intestine: (clean-contamined) (radical } \\
\text { cystectomy + ileal conduit) } \\
\text { Cefoxitin }\end{array}$ & $\begin{array}{l}\text { Open/laparoscopic surgery involving } \\
\text { intestine: (clean-contamined) (radical } \\
\text { cystektomy + ileal conduit) Metronidazole + } \\
\text { levofloxacin }\end{array}$ \\
\hline & $\begin{array}{l}\text { If prosthetic material involved in urologic } \\
\text { procedures, should add one-time dose of } \\
\text { gentamicin }\end{array}$ & $\begin{array}{l}\text { If prosthetic material involved in urologic } \\
\text { procedures, should add one-time dose of } \\
\text { gentamicin if not already given }\end{array}$ \\
\hline \multicolumn{3}{|c|}{$\begin{array}{l}{ }^{1} \text { Clindamycin can be used as an alternative to vancomycin. Clindamycin and vancomycin are recommended alternative agents to cefazolin for patients with beta-lactam allergies, } \\
{ }^{2} \text { Urology notes, }{ }^{2 a l} \text { If significant concern for methicillin-resistant Staphylococcus aureus, vancomycin should be considered as an alternative to clindamycin, }{ }^{20} \text { Ciprofloxacin is a } \\
\text { reasonable alternative. However, according to the } 2015 \text { SHC antibiogram, more Escherichia coli isolates were susceptible to aminoglycosides than fluoroquinolones (http://lane. } \\
\text { stanford.edu/biomed-resources/antibiograms-shc.html) }\end{array}$} \\
\hline
\end{tabular}




\section{- Non-parenteral Antimicrobial Prophylaxis}

The existing randomized controlled trials present contradictory data concerning the benefits and ill effects of intraoperative antimicrobial irrigation (e.g., intra-abdominal, deep or subcutaneous tissues) in preventing SSIs (no recommendation/ unresolved issue) (20). Two clinical practice guidelines based on reviewing evidence suggest using antimicrobial wound irrigation or intracavity lavage to reduce the risk of SSI $(1,27)$.

There is no randomized controlled study that evaluated soaking prosthetic devices in antimicrobial solutions before implantation for the prevention of SSIs (no recommendation/unresolved issue) (20).

Antimicrobial agents (e.g., ointments, solutions or powders) should not be applied to surgical incision to prevent SSIs (category IB) (20). However, clinical practice guidelines have different approaches concerning the recommendation of the application of non-parenteral antimicrobials to surgical incision in the absence of SSIs $(27,33)$.

Autologous platelet-rich plasma transfusion (spray or gel) is not considered necessary for the prevention of SSIs (category II) (20).

The use of triclosan-coated sutures should be considered for preventing SSIs (category II) (20).

In randomized controlled trials in the literature, it has been suggested that there was uncertainty regarding the benefits and ill effects associated with antimicrobial dressings applied to surgical incisions following primary closure in the operating room (no recommendation/unresolved issue) (20).

\section{Current Recommendations on Prophylaxis in Urological Surgery}

EAU Panel of Urological Infection Guidelines consists of a group of urologists with expertise in this field and in infectious diseases. These Urological Infection Guidelines, first published in 2001 and revised in 2017, state that the infection risk varies according to the type of intervention, and there are no clear instructions concerning antimicrobial prophylaxis due to the wide variety of the intervention types and the recent developments in minimally invasive surgery; thus, these guidelines propose evaluating the requirements of each case individually to make a decision about prophylaxis (34). Furthermore, according to the EAU guidelines, when selecting antimicrobial agents, the role of local pathogen profiles, pathogen susceptibility and virulence, procedurespecific risk factors, contamination load, target organ and local inflammation should be taken into consideration (34). Table 3 presents the recommendations on antimicrobial prophylaxis according to surgical procedure. In cases where antimicrobial prophylaxis is indicated, fluoroquinolones, trimethoprim \pm sulfamethoxazole, aminopenicillin/beta-lactamase inhibitor, second- or third-generation cephalosporin, or even piperacillin/ tazobactam are among the recommended agents.

\section{Prophylaxis in Diagnosis}

\section{- Cystoscopy}

The frequency of infectious complications reported after cystoscopy, standard urodynamic investigation and ureteroscopy is very low if the urine is sterile in the preoperative period (35). Routine antimicrobial prophylaxis is not recommended due to the frequency of diagnostic cystoscopy, low risk of infection, and developing bacterial resistance (34). However, bacteriuria, permanent catheterization, neurogenic lower urinary tract disease, and urogenital infection history are among the risk factors that should be considered (36).

\section{- Transrectal Prostate Biopsy}

It has been found that administration of antimicrobial prophylaxis in transrectal prostate biopsy significantly reduces the risk of infection after the procedure (37); therefore, antimicrobial prophylaxis is recommended after transrectal biopsy (34). Although fluoroquinolones are the most frequently used agents in prophylaxis, the duration of prophylaxis and the choice of antibiotics should be discussed first (34). It has also been reported that the use of fosfomycin trometamol or prophylactic antimicrobial based on rectal swab is currently being investigated as an alternative to antimicrobial prophylactic agents, meta-analyses are being undertaken, and new recommendations on prophylaxis will be included in guidelines to be published in the following years $(38,39,40)$.

\section{Prophylaxis in Endourological Treatment Procedures (Urinary Tract Entered)}

\section{- Transurethral Resection of the Bladder}

There is limited evidence of the benefit of antimicrobial prophylaxis before transurethral resection of the bladder (34). In studies on the benefits of prophylaxis, no distinction has been made concerning simple fulguration, large or multiple tumors, or presence of necrotic material. Therefore, the present guidelines recommend the selection of appropriate prophylaxis depending on the tumor differentiation.

\section{- Transurethral Resection of the Prostate}

According to the results of a considerable number of studies undertaken on this procedure, antimicrobial prophylaxis 
Table 3. Recommendations for propylactic agent in urological surgery (33)

\begin{tabular}{|c|c|}
\hline Surgical procedure & Antimicrobial prophylaxis \\
\hline \multicolumn{2}{|l|}{ Diagnostic procedures } \\
\hline Cystoscopy & - \\
\hline \multirow[t]{2}{*}{ Transrectal core biopsy of prostate } & Fluoroquinolones \\
\hline & Trimethoprim \pm sulphamethoxazole \\
\hline \multicolumn{2}{|l|}{ Endourological/endoscopic therapeutic procedures } \\
\hline Fulguration of small baldder tumours & Optional \\
\hline Transurethral resection of the bladder & Trimethoprim \pm sulphamethoxazole \\
\hline Transurethral resection of the prostate & Aminopenicillin / beta-lactamase inhibitor \\
\hline Shock-wave lithotripsy & Cephalosporin (2 or 3. group) \\
\hline Nephrectomy \pm ureterectomy & Optional \\
\hline \multicolumn{2}{|l|}{ Adrenalectomy } \\
\hline \multicolumn{2}{|l|}{ Radical prostatectomy } \\
\hline Planned scrotal surgery, vasectomy, varicocele surgery & - \\
\hline Prosthetic implants & Aminopenicillin/beta-lactamase inhibitor \\
\hline Artificial sphincter & Piperacillin/tazobactam \\
\hline Ureteropelvic junction repair & Optional \\
\hline Partial bladder resection & Optional \\
\hline Cystectomy with urine deviation & Cefuroxim \\
\hline
\end{tabular}

significantly reduces bacteriuria and septicemia, and prophylactic agents before transurethral resection of the prostate is recommended (35).

\section{- Ureteroscopy}

There are no prospective controlled studies evaluating the use of prophylactic agents in ureteroscopy (34). The current guidelines state that a differentiation should be made between diagnoses in healthy individuals pertaining to low-risk procedures, such as treatment of distal ureteral stones and high-risk procedures; e.g., treatment of obstructing proximal stones. Therefore, it is advisable to take the decision concerning prophylactics based on patient-related risk factors (41).

\section{- Percutaneous Nephrolithotripsy}

It has been shown that the infection risk is high in percutaneous nephrolithotripsy and retrograde intrarenal stone treatment, and prophylactic antibiotics significantly reduce the risk of infectious complications $(41,42)$. It has been noted that in these cases, a single dose of prophylactic antibiotics is sufficient (43).

\section{- Extracorporeal Shock Wave Lithotripsy}

Antimicrobial prophylaxis is not recommended as a standard application in extracorporeal shock wave lithotripsy (35). However, it is indicated to use prophylaxis for the control of bacteriuria and in elevated bacterial load, such as permanent catheter, nephrostomy tube, or presence of infective stones (44).

\section{- Laparoscopic Surgery}

Although there are not an adequate number of studies on antimicrobial prophylaxis in laparoscopic surgery, it seems reasonable to follow the recommendations provided for open surgical interventions (34).

\section{- Nephrectomy, Adrenalectomy}

Although antimicrobial prophylaxis is not recommended as standard, it has been reported that in some cases, its use can be assessed at the discretion of the surgeon (45).

\section{- Prostatectomy}

Antimicrobial prophylaxis is recommended in open enucleation of prostate adenoma due to the high risk of postoperative 
infection (46). It has been reported that since there is no clear data concerning antimicrobial prophylaxis in radical prostatectomy, this application should be undertaken at the discretion of the surgeon (34).

\section{- Cystectomy + Ileal Conduit}

The evidence obtained is mostly based on colorectal surgery, and there is only limited data on surgical interventions in urology $(19,47)$. It is recommended to use prophylactic antibiotics as a single dose or for the first 12 hours, however, antimicrobial therapy may be continued up to 72 hours in the presence of factors, such as prolonged surgery or comorbid risk status (34). Antibiotic agents selective to aerobic and anaerobic pathogens should be used.

- Prosthetic Implantation: Testis, Penile Prosthesis and Artificial Sphincter

Infectious complications in implant surgery are usually problematic and cause the removal of the prosthesis (48); thus, antimicrobial prophylaxis is recommended (34).

\section{Conclusion}

Since SSIs are healthcare-related infections, it is important to effectively prevent patients from contracting them. The number of applications for the protection against SSIs is increasing, which in turn raises the demand for interventions based on evidence. Therefore, there is a need to revise the previously published guidelines. New and updated recommendations will be a guide for not only healthcare professionals, but also for professional associations and organizations. These revisions can also be used to develop more detailed implementation guidelines based on previous documents and identify future research priorities. The unresolved issues mentioned in the revised guidelines refer to important points that need to be investigated in the future. For this reason, there is a need for further well-designed studies.

\section{Ethics}

Peer-review: Externally peer-reviewed.

\section{Authorship Contributions}

Surgical and Medical Practices: P.Ş., T.D., Concept: P.Ş., T.D., Design: P.S., T.D., Data Collection or Processing: P.S.., T.D., Analysis or Interpretation: P.Ş., T.D., Literature Search: P.Ş., T.D., Writing: P.Ş., T.D.

Conflict of Interest: No conflict of interest was declared by the authors.

Financial Disclosure: The authors declared that this study has received no financial support.

\section{References}

1. World Health Organization; 2016. Global Guidelines for the Prevention of Surgical Site Infection. 2016; http://apps.who.int/iris/bitstre am/10665/250680/1/9789241549882-eng.pdf?ua=1. Accessed August 8, 2017.

2. Gunaydın $M$, Erdoğan $M$. Güncel Bilgiler Işığında Cerrahi Alan İnfeksiyonu Nedir, Ne Değildir? 31. ANKEM Akılcı Antibiyotik Kullanım Kongresi, 4-8 Mayıs 2016.

3. Magill SS, Hellinger W, Cohen J, Kay R, Bailey C, Boland B, Carey D, de Guzman J, Dominguez K, Edwards J, Goraczewski L, Horan T, Miller M, Phelps M, Saltford R, Seibert J, Smith B, Starling P, Viergutz B, Walsh K, Rathore $M$, Guzman N, Fridkin S. Prevalence of healthcare-associated infections in acute care hospitals in Jacksonville, Florida. Infect Control Hosp Epidemiol 2012;33:283-291.

4. UHESA Özet raporu 2014: http://www.saglik.gov.tr/TR/dosya/197084/ h/2014-ulusal-ozet-rapor-1.pdf. Erişim: 8 Ağustos 2017.

5. Mu Y, Edwards JR, Horan TC, Berrios-Torres SI, Fridkin SK. Improving riskadjusted measures of surgical site infection for the national healthcare safety network. Infect Control Hosp Epidemiol 2011;32:970-986.

6. DeFrances CJ, Podgornik MN. 2004 National Hospital Discharge Survey. Adv Data 2006:1-19.

7. Umscheid CA, Mitchell MD, Doshi JA, Agarwal R, Williams K, Brennan PJ. Estimating the proportion of healthcare-associated infections that are reasonably preventable and the related mortality and costs. Infect Control Hosp Epidemiol 2011;32:101-114.

8. Aygin D, Marul F. Cerrahi Alan Enfeksiyonu Tanımlarında Yenilikler ve Ameliyat Öncesi Tüy Temizliğinde Güncel Uygulamalar. Online Türk Sağlık Bilimleri Dergisi, 2016;1:28-36.

9. Awad SS. Adherence to surgical care improvement Project measures and post-operative surgical site infections. Surg Infect (Larchmt) 2012;13:234237.

10. Bruce J, Russell EM, Mollison J, Krukowski ZH. The quality of measurement of surgical wound infection as the basis for monitoring: a systematic review. J Hosp Infect 2001;49:99-108.

11. National Healthcare Safety Network, Centers for Disease Control and Prevention. Surgical site infection (SSI) event. http://www.cdc.gov/nhsn/ pdfs/pscmanual/9pscssicurrent.pdf. Published January 2017. Accessed August 8, 2017.

12. Jarvis WR. Benchmarking for prevention: the Centers for Disease Control and Prevention's National Nosocomial Infections Surveillance (NNIS) system experience. Infection 2003;31(Suppl 2):44-48.

13. Fry DE. Fifty ways to cause surgical site infections. Surg Infect (Larchmt) 2011;12:497-500.

14. Centers for Disease Control and Prevention. The direct medical costs of healthcare-associated infections in U.S. hospitals and the benefits of prevention. http://www.cdc.gov/hai/pdfs/hai/scott_costpaper.pdf. Published 2009. Accessed August 8, 2017.

15. Sievert DM, Ricks P, Edwards JR, Schneider A, Patel J, Srinivasan A, Kallen A Limbago B, Fridkin S; NationalHealthcare Safety Network (NHSN) Team and Participating NHSN Facilities. Antimicrobial resistant pathogens associated with health care associated infections: summary of data reported to the National Healthcare Safety Network at the Centers for Disease Control and Prevention, 2009-2010. Infect Control Hosp Epidemiol 2013;34:1-14.

16. Buggy D. Can anaesthetic management influence surgical wound healing? Lancet 2000;356:355-357.

17. Korol E, Johnston K, Waser N, Sifakis F, Jafri HS, Lo M, Kyaw MH. A systematic review of risk factors associated with surgical site infections among surgical patients. PLoS One 2013;8:e83743. 
18. Culver DH, Horan TC, Gaynes RP, Martone WJ, Jarvis WR, Emori TG, Banerjee SN, Edwards JR, Tolson JS, Henderson TS, et al. Surgical wound infection rates by wound class, operative procedure, and patient risk index. National Nosocomial Infections Surveillance System. Am J Med 1991;91:152-157.

19. Mangram AJ, Horan TC, Pearson ML, Silver LC, Jarvis WR. Guideline for Prevention of Surgical Site Infection, 1999. Centers for Disease Control and Prevention (CDC) Hospital Infection Control Practices Advisory Committee. Am J Infect Control 1999;27:97-132.

20. Berrios-Torres SI, Umscheid CA, Bratzler DW, Leas B, Stone EC, Kelz RR, Reinke CE, Morgan S, Solomkin JS, Mazuski JE, Dellinger EP, Itani KMF, Berbari EF, Segreti J, Parvizi J, Blanchard J, Allen G, Kluytmans JAJW, Donlan $\mathrm{R}$, Schecter WP; Healthcare Infection Control Practices Advisory Committee. Centers for Disease Control and Prevention Guideline for the Prevention of Surgical Site Infection, 2017. JAMA Surg 2017;152:784-791.

21. Bratzler DW, Dellinger EP, Olsen KM, Perl TM, Auwaerter PG, Bolon MK, Fish DN, Napolitano LM, Sawyer RG, Slain D, Steinberg JP, Weinstein RA; American Society of Health-System Pharmacists; Infectious Disease Society of America; Surgical Infection Society; Society for Healthcare Epidemiology of America. Clinical practice guidelines for antimicrobial prophylaxis in surgery. Am J Health Syst Pharm 2013;70:195-283.

22. Center for Infectious Disease Research and Policy. Antimicrobial Surgical Prophylaxis - SHC guidelines for Adult Patients. http://www.cidrap.umn. edu/asp/clinicaltools/antimicrobial-surgical-prophylaxis-shc-guidelinesadult-patients. Accessed September 7, 2017.

23. American College of Obstetricians and Gynecologists. ACOG Practice Bulletin No. 120: Use of prophylactic antibiotics in labor and delivery. Obstet Gynecol 2011;117:1472-1483.

24. Anderson DJ, Podgorny K, Berríos-Torres SI, Bratzler DW, Dellinger EP, Greene L, Nyquist AC, Saiman L, Yokoe DS, Maragakis LL, Kaye KS. Strategies to prevent surgical site infections in acute care hospitals: 2014 update. Infect Control Hosp Epidemiol 2014;35(Suppl 2):66-88.

25. No authors listed. Antimicrobial prophylaxis for surgery. Treat Guidel Med Lett 2012;10:73-78.

26. Bauer LA, Edwards WA, Dellinger EP, Simonowitz DA. Influence of weight on aminoglycoside pharmacokinetics in normal weight and morbidly obese patients. Eur J Clin Pharmacol 1983;24:643-647.

27. National Institute for Health and Clinical Excellence (NICE). Surgical Site Infection: Prevention and Treatment of Surgical Site Infection (NICE Clinical Guideline 74). 2008; https://www.nice.org.uk/guidance/cg74. Accessed August 8, 2017.

28. Tamayo E, Gualis J, Florez S, Castrodeza J, Eiros Bouza JM, Alvarez FJ. Comparative study of single-dose and 24-hour multiple-dose antibiotic prophylaxis for cardiac surgery. J Thorac Cardiovasc Surg 2008;136:15221527.

29. Turano A. New clinical data on the prophylaxis of infections in abdominal, gynecologic, and urologic surgery. Multicenter Study Group. Am J Surg 1992;164(4A Suppl):16-20.

30. Ali M, Raza A. Role of single dose antibiotic prophylaxis in clean orthopedic surgery. J Coll Physicians Surg Pak 2006;16:45-48.

31. Conte JE Jr, Cohen SN, Roe BB, Elashoff RM. Antibiotic prophylaxis and cardiac surgery. A prospective double-blind comparison of single-dose versus multiple-dose regimens. Ann Intern Med 1972;76:943-949.

32. Nooyen SM, Overbeek BP, Brutel de la Riviere A, Storm AJ, Langemeyer JJ. Prospective randomised comparison of single-dose versus multiple-dose cefuroxime for prophylaxis in coronary artery bypass grafting. Eur J Clin Microbiol Infect Dis 1994;13:1033-1037.

33. Engelman R, Shahian $D$, Shemin R, Guy TS, Bratzler D, Edwards $F$, Jacobs $M$, Fernando H, Bridges $C$; Workforce on Evidence-Based Medicine, Society of Thoracic Surgeons. The Society of Thoracic Surgeons practice guideline series: Antibiotic prophylaxis in cardiac surgery, part II: Antibiotic choice. Ann Thorac Surg 2007;83:1569-1576.

34. Bonkat $G$, Pickard $R$, Bartoletti $R$, Bruyère $F$, Geerlings $S E$, Wagenlehner F, Wullt B, Guidelines Associates: Cai T, Köves B, Pilatz A, Pradere B, Veeratterapillay R. EAU Guidelines on Urological Infections. Retrieved from: http://uroweb.org/guideline/urological-infections. Accessed August 10, 2017.

35. Alsaywid BS, Smith GH. Antibiotic prophylaxis for transurethral urological surgeries: Systematic review. Urol Ann 2013;5:61-74.

36. Latthe PM, Foon R, Toozs-Hobson P. Prophylactic antibiotics in urodynamics: a systematic review of effectiveness and safety. Neurourol Urodyn 2008;27:167-173.

37. Yang L, Hu J, Wei H, Wang L, Zhong H. Clinical significance of antibiotic prophylaxis for transrectal prostate biopsy. Zhonghua Wai Ke Za Zhi 2001;39:940-942.

38. Boeri L, Fontana M, Gallioli A, Zanetti SP, Catellani M, Longo F, Mangiarotti B, Montanari E. Rectal Culture-Guided Targeted Antimicrobial Prophylaxis Reduces the Incidence of Post-Operative Infectious Complications in Men at High Risk for Infections Submitted to Transrectal Ultrasound Prostate Biopsy -Results of a Cross-Sectional Study. PLoS One 2017;12:e0170319.

39. Sen $V$, Aydogdu O, Bozkurt IH, Yonguc T, Sen P, Polat S, Degirmenci T, Bolat $D$. The use of prophylactic single-dose fosfomycin in patients who undergo transrectal ultrasound-guided prostate biopsy: A prospective, randomized, and controlled clinical study. Can Urol Assoc J 2015;9:863-7.

40. Ongün S, Aslan G, Avkan-Oguz V. The effectiveness of single-dose fosfomycin as antimicrobial prophylaxis for patients undergoing transrectal ultrasound-guided biopsy of the prostate. Urol Int 2012;89:439-444.

41. Martov A, Gravas S, Etemadian M, Unsal A, Barusso G, D'Addessi A, Krambeck A, de la Rosette J; Clinical Research Office of the Endourological Society Ureteroscopy Study Group. Postoperative infection rates in patients with a negative baseline urine culture undergoing ureteroscopic stone removal: a matched case-control analysis on antibiotic prophylaxis from the CROES URS global study. J Endourol 2015;29:171-180.

42. Dasgupta R, Grabe M. Preoperative antibiotics before endourologic surgery: current recommendations. J Endourol 2009;23:1567-1570.

43. Seyrek $M$, Binbay $M$, Yuruk $E$, Akman $T$, Aslan R, Yazici O, Berberoglu $Y$, Muslumanoglu AY. Perioperative prophylaxis for percutaneous nephrolithotomy: randomized study concerning the drug and dosage. J Endourol 2012;26:1431-1436.

44. Lu $Y$, Tianyong $F$, Ping $H$, Liangren $L$, Haichao $Y$, Qiang W. Antibiotic prophylaxis for shock wave lithotripsy in patients with sterile urine before treatment may be unnecessary: a systematic review and meta-analysis. J Urol 2012;188:441-448.

45. Steiner $T$, Traue C, Schubert J. Perioperative antibiotic prophylaxis in transperitoneal tumor nephrectomy: does it lower the rate of clinically significant postoperative infections? Urologe A 2003;42:34-37.

46. Richter $S$, Lang R, Zur F, Nissenkorn I. Infected urine as a risk factor for postprostatectomy wound infection. Infect Control Hosp Epidemiol 1991;12:147-149.

47. Hara N, Kitamura $Y$, Saito $T$, Komatsubara $S$, Nishiyama T, Takahashi K. Perioperative antibiotics in radical cystectomy with ileal conduit urinary diversion: efficacy and risk of antimicrobial prophylaxis on the operation day alone. Int J Urol 2008;15:511-515.

48. Carson CC. Diagnosis, treatment and prevention of penile prosthesis infection. Int J Impot Res 2003;15(Suppl 5):139-146. 